\title{
A Comparative Analysis of Resilience of Islamic and Conventional Banks in Indonesia
}

\author{
Sri Ulina ${ }^{1}$, M. Shabri Abd. Majid ${ }^{2 *}$ \\ Universitas Syiah Kuala, Banda Aceh, Indonesia ${ }^{1}{ }^{2}$
}

Submitted: 2 June 2020; Accepted: 25 November 2020; Published: 1 December 2020

\begin{abstract}
The presence of the 2008 Global Financial Crisis (GFC) has adversely impacted both conventional and Islamic banking performances. This study aims to empirically compare the financial performances between Islamic banks and conventional banks during the pre- and post-2008 GFC periods. It also attempts to compare the financial performance of each Islamic and conventional bank between the pre- and post-2008 GFC periods. Three state-owned banks from each conventional and Islamic banking category were selected as the study sample using the purposive sampling technique. Based on the independent sample t-test, the study found a significant difference between the Islamic and conventional banking performances during the pre- and post-2008 GFC periods. Meanwhile, based on the paired t-test, the decline in Islamic banking performance from the pre-2008 GFC to the post-2008 GFC periods was significantly smaller than their conventional banking counterparts. These findings show the Islamic banks' superiority over their conventional banking counterparts due to fair and just practices based on Islamic tenets. Due to their reliance in facing the episodes of crises, the Islamic banks deserve a strong support by government by enhancing prudent Islamic banking regulation. The Islamic banks should strive to operate fully based on the shari'ah principles and prudent banking management.
\end{abstract}

Keywords: banks' performances, conventional banks, Islamic banks, 2008 global financial crisis 


\section{INTRODUCTION}

Throughout history, the economic crisis has repeatedly occurred in the world economy. During the $20^{\text {th }}$ century, at least 20 times of major economic crises have hit many countries (Davies, 2002). This fact shows that, on average, the major financial crisis occurs once in every five years. The crisis has adversely impacted the welfare of the community and devastated the national economy for a certain period as it took a long time and a great effort to recover from the economic downturn.

During the 21 st century, the world was again shocked by the 2008 global financial crisis that started in the US. The crisis has been claimed as the worst financial crisis since the 1930s Great Depression by George Soros, Joseph Stiglitz, the IMF, and other economists (Tong \& Wei, 2008; Majid \& Kassim, 2009; Kassim, Majid, \& Yusof, 2009; Kassim \& Majid, 2010; Kassim, Majid, \& Hamid, 2011). This event stems from the announcement of the largescale French bank, BNP Paribas, about the freezing of high-risk of the US home mortgage stocks, or better known with the term subprime mortgages since August 2007. As a result, various reactions emerged in the financial markets, and in the end, the impact spread to multiple countries(Majid \& Kassim, 2009; Kassim et al., 2009;Kassim et al., 2011;Majid, 2018).

At the end of the $3^{\text {rd }}$ quarter of 2008, the crisis worsened along with the bankruptcy of the largest investment bank in the US, Lehman Brothers, followed by several other banks such as Bear Stearns, Fannie Mae and Freddie Mac, and American International Group (AIG) Incorporated. The worsening crisis also affected the collapse of stock prices and the bankruptcy of many financial institutions both in developed and developing countries. International-scale banks, particularly in Europe and the US also suffered huge losses, such as Citigroup by USD55.1 billion, Union Bank of Switzerland (UBS) by USD44.2 billion, Merril Lynch Company by USD52.2 billion, and the Hong Kong and Shanghai Banking Corporation (HSBC) Limited by USD 27.4 billion(Pratikto \& Sugianto, 2011).

Despite having strong economic fundamentals (Sugema, 2012), Indonesia also hit by the 2008 global financial crisis as seen from reactions in the capital market and financial markets (Bank Indonesia, 2009). In the end of 2008, the stock price index in Indonesia fell by $48.41 \%$ from 2,627.3 points from the beginning of 2008, and at the same time, the value of market capitalization and trading volume declined sharply. The banking industry was also adversely affected by the crisis because foreign investors had withdrawn their investment funds in some companies. As a result, the value of productive assets in the number of banks decreased both in the form of loans and securities purchased by banks. Likewise, the banks' capital adequacy also dramatically reduced due to losses from the decline in the quality of productive assets and increased non-performing loans (Sudarsono, 2009). Three state-owned banks 
requested liquidity assistance of IDR5 trillion in October 2008 from the government of Indonesia(Islamic Bank Indonesia, 2010).

In Indonesia, Islamic banks operate in parallel with conventional banks and Islamic banks in a dual banking system. Unlike conventional interest-based banking, Islamic banks carry out their intermediary activities of collecting and channelling funds that are interest-free and following Islamic principles. Although Islamic banks are relatively new compared to conventional banks that have existed since the last three decades, they have experienced promising progress since the launch of the first Islamic banks in Indonesia, namely Bank Muamalat Indonesia in 1991. Since then, the number of Islamic banks has continuously increased. In 2015, there were 12 Islamic banks and increased to 14 Islamic banks in 2017 due to the conversion of the Bank of Aceh and the Bank of West Nusa Tenggara (NTB) to full-fledged Islamic banks (Otoritas Jasa Keuangan, 2018).

Even though Islamic banks have proven to be able to survive during the 1997 East Asian economic crisis, Islamic banks were also adversely impacted by the 2008 Global Financial Crisis (GFC). However, the effect of 2008 GFC on the Islamic bank was far smaller than their conventional counterparts. This finding is as evidenced by Kassim and Majid (2010), who found that although Islamic banks are more resilient to the economic crisis, Islamic banks are also vulnerable to financial crises. This is contrary to popular belief so far that the Islamic financial system is fully protected from the crisis because of its interest-free nature.

The presence of 2008 GFC has positioned the banks in a more difficult situation, considering the fierce competition due to the decline in banking performance. Banks as intermediary financial institutions, which collect and distribute funds from and to the public, their business continuity are highly dependent on their ability to cope with the impacts of the crisis to maintain good performances. The degree of impact of the crisis and kinds of strategy to preserve performances are among the critical factors determining the success of banks' competition.

Competition between Islamic banks and conventional banks is very dependent on the financial performance of the bank itself. The financial performance of a bank reflects the health condition of the bank. By having a good bank performance, the bank can provide better services and benefits to internal and external parties of the bank(Betharino, Susanti, \& Joko, 2015). For this reason, research on measuring and enhancing financial performance is increasingly important so that banks can fulfil all functions, roles, and objectives. If the banks can shield themselves from the impact of the crisis, the banks would easily maintain good financial performance amid an economic crisis. 
Many previous studies have been conducted to measure Islamic banking performance in other countries and Indonesia. For example, Rosly and Bakar (2003) and Wasiuzzaman and Gunasegavan (2013) measured Islamic banking performance in Malaysia using its average value. Jaffar and Manarvi (2011) and Khan, Khan, and Tahir (2017) measured Islamic banking performance in Pakistan using Capital, Asset Quality, Management, Earning, and Liquidity approaches (CAMEL) approaches, while Erol, Baklaci, Aydoğan, and Tunç, (2014) measured Islamic banking performance using the CAMEL approach in Turkey. All of these studies only measured the performances of Islamic banks and did not compare them with conventional banking performances.

Previous studies comparing Islamic banks' performance with conventional banks have been conducted by Hazzi and Kilani (2013) in Malaysia, using an independent sample t-test. However, the study did not compare the performance of banks between various periods of economic crisis. In the context of Indonesia, previous studies comparing the financial performance of Islamic banks have been conducted by Winarso (2008), Pratikto and Sugianto (2011), and Sabbina (2014). However, their studies only compared the financial performance of Islamic banks and ignored its comparison with conventional banks.

In Indonesia, the comparative financial performance of conventional banks and Islamic banks in Indonesia has been studied by Subaweh (2008), Ardiyana (2011), Setyaningsih and Utami (2013), Nugraha (2014), and Betharino et al (2015). However, their sample selection consists of few conventional and Islamic banks for a maximum of the fiveyear study period. Besides, these studies did not compare the banking performance across the economic crisis period.

Referring to the above-reviewed studies, it is clear that there are still shortcomings from previous studies so as to provide space for this research to fill it. More specifically, this study aims to empirically compare between conventional and Islamic banking performances in the pre- and post-2008 GFC periods. In contrast to previous studies, the main novelty of this study is in terms of examining more conventional banks and Islamic banks with a more extended and updated study period of five years (i.e., 2003-2007) before the 2008 Global Financial Crisis (GFC) and nine years (i.e., 2009-2017) after the 2008 GFC. Besides, the study also attempts to compare the differences in Islamic banking performances between the pre- and post-2008 GFC periods.

The findings of this study are expected to provide additional useful references for academicians and researchers about the comparative financial performances between Islamic and conventional banks over the pre-and post-2008 GFC periods. The study results are also expected to be beneficial to the management of Islamic and conventional banks as a reference 
for policy-making to improve financial performance amid increasingly competitive competition and uncertain economic conditions.

\section{METHOD}

Using a monthly data over the 2003-2017 period, this study compares the financial performances between Islamic banks and conventional banks during the pre- and post-2008 Global Financial Crisis (GFC). In addition, this study also compares the financial performance of each Islamic and conventional bank between the pre- and post-2008 GFC periods.

In this study, the period before the 2008 GFC comprises five years (60 observations), spanning from 2003 to 2007, while the period after the 2008 GFC consists of nine years (108 observations), ranging from 2009 to 2017 . As for the pre- and post-2008 GFC periods' analyses, the study exclude the year of crisis (i.e., 2008) to eliminate the effect of crisis year on the analysis. However, for the entire period analysis, the study incorporates entire 15-year period (180 observations), spanning from 2003 to 2017. The monthly data of bank financial statements in the form of financial ratios were calculated from the reports of each bank and used to measure the financial performance of Islamic banks and conventional banks. These secondary data were gathered from several sources, namely from the website of Otoritas Jasa Keuangan (www.ojk.go.id) and the banks' financial statements that have been published on their websites.

The population of this study consists of all commercial banks in Indonesia, namely 115 conventional commercial banks and 13 Islamic commercial banks. Three state-owned banks for each category were selected as the sample of the study using the purposive sampling technique. These conventional banks include Bank Rakyat Indonesia, Bank Negara Indonesia, and Bank Mandiri, while the three selected Islamic banks include Bank Muamalat Indonesia, Bank Syariah Mandiri, and Bank Mega Syariah. The selected banks were those who published a complete monthly financial report during the study period from 2003 to 2017, and the stateowned banks that recorded the top-three most substantial assets from each banking system category.

In this study, financial performance is defined as the ability of banks to generate net income based on the level of assets owned(Rose \& Hudgins, 2005). Financial performance is measured using the financial ratio of Returns on Assets (ROA), which is the amount of profit after tax divided by the total amount of bank assets. The use of ROA in this study is due to its ability to provide a manager, investor, or analyst an idea as to how efficient a company's management is at using its assets to generate earnings. ROA also resolves a major shortcoming of other banking performance measures, such as Return on Equity (ROE) that fails to show if a 
bank has excessive debt or is using debt to drive returns. In addition, the use of ROA is more appropriate to measure bank performance than the Return on Investment (ROI). ROI is an analysis of performance parameters based on a given investment, while the ROA corresponds to the total asset of a business or investment portfolio of an investor. Thus, ROA is able to show the real conditions of the bank in generating profit based on the given amount of assets or how a bank is actually behaving in terms of converting assets into net capital. Many previous studies have adopted ROA to measure banking performance (Aliabadi, Dorestani, \& Balsara, 2013; and Kopecká, 2018).

Furthermore, to test the differences in financial performance between conventional banks and Islamic banks in the pre- and post-2008 GFC periods, an independent sample t-test was used. Meanwhile, to examine differences in financial performance between the pre- and post-2008 GFC periods of a similar banking group, the study uses a paired sample t-test or a dependent t-test.

\section{RESULTS AND DISCUSSION}

This section provides and discusses the findings of the study into several sub-sections, namely descriptive statistics, correlation coefficients, comparison between financial performance of Islamic banks and conventional banks both in the pre- and post-2008 GFC periods, and comparison of financial performances of each Islamic and conventional bank between the preand post-2008 GFC periods, as well as the implications of research findings.

Before presenting and discussing differences in banking performances in the pre-and post-2008 GFC periods, the study provides and explains the descriptive statistics of both conventional and Islamic banking performances.

As illustrated in Table 1, the financial performance of the conventional banks was higher than that of Islamic banks, as shown by the ratio of Returns on Assets (ROA) over different sample periods. On average, the conventional banks' financial performance has declined from 5.72 points in the pre-2008 GFC (i.e., 2003-2007) to 3.35 points in the post-2008 GFC (i.e., 2009 to 2017) periods. Overall, their performances were 4.27 points for the entire sample (i.e., 2003-2017). On the other hand, on average, the Islamic banks' financial performance has declined from 2.43 points in the pre-2008 GFC to 1.46 points in the post-2008 GFC periods. Overall, their performances were 4.27 points for the entire study sample. These findings show that the conventional and Islamic banking performances have declined by $70.75 \%$ and $-66.44 \%$, respectively, from the pre- to the post-2008 GFC periods. 
Table 1. Descriptive StatisticsBank's Financial

\begin{tabular}{lcccc}
\hline $\begin{array}{c}\text { Bank's Financial } \\
\text { Performance }\end{array}$ & Minimum & Maximum & Mean & Standard deviation \\
\hline \multicolumn{5}{c}{ Sub -sample 1: Pre - 2008 GFC } \\
\hline Conventional Bank & 2.53 & 11.84 & 5.72 & 2.78 \\
Islamic Bank & -0.89 & 5.97 & 2.43 & 1.33 \\
\hline \multicolumn{5}{c}{ Sub -sample 2: Post - 2008 GFC } \\
\hline Conventional Bank & 1.11 & 5.15 & 3.35 \\
Islamic Bank & -1.21 & 4.86 & 1.46 & 1.09 \\
\hline \multicolumn{5}{c}{ Full-sample: Pre-and Post-2008 GFC } \\
\hline Conventional Bank & 1.11 & 11.80 & 4.27 & 2.18 \\
Islamic Bank & -1.21 & 5.36 & 1.85 & 1.24 \\
\hline
\end{tabular}

These findings show that the decline in the financial performance of the conventional banks was higher by $4.31 \%$ than that of Islamic banks counterparts. In other words, the conventional banks have experienced a more volatile financial performance as compared to the Islamic banks over the 2003-2017 period. This finding is also evidenced by a larger value of the conventional banks' standard deviations from their Islamic banks' counterparts over a different sample of the study period. These findings also provide initial evidence of better performance and more resilience of the Islamic banks towards the economic crisis. To further confirm the significant differences in their banking performances, the study would conduct the independent and paired t-tests in the next section.

However, these preliminary empirical findings are supported by Kassim and Majid (2010). They documented that the 1997- and 2008-financial crises have caused more deterioration of conventional banks than Islamic banks in Malaysia. Our findings also support the depositors' belief that Islamic banks were more resilient in facing a financial crisis that has attracted more inflow of deposits into the banks during the 2008 financial crisis (Abduh, Omar, \& Duasa, 2011).

Table 2 further illustrates the mean performance of each bank over the periods of analysis. In line with Table 1, Table 2 shows that all conventional banks recorded higher financial performance as compared to all Islamic banks during the pre-2008 GFC, post-2008 GFC, and pre- and post-2008 GFC periods. 
Table 2. The Mean of Banking Performance

\begin{tabular}{lccc}
\hline \multicolumn{1}{c}{ Conventional Bank } & $\begin{array}{c}\text { Sub-sample 1: } \\
\text { Pre- 2008 GFC }\end{array}$ & $\begin{array}{c}\text { Sub-sample 2: } \\
\text { Post- 2008 GFC }\end{array}$ & $\begin{array}{c}\text { Entire sample: } \\
\text { Pre- and Post -2008 GFC }\end{array}$ \\
\hline Bank Rakyat Indonesia & 9.06 & 4.22 & 6.12 \\
Bank Negara Indonesia & 3.81 & 2.69 & 3.03 \\
Bank Mandiri & 4.27 & 3.15 & 3.65 \\
\hline Mean & $\mathbf{5 . 7 2}$ & $\mathbf{3 . 3 5}$ & $\mathbf{4 . 2 7}$ \\
\hline \multicolumn{1}{c}{ Islamic Bank } & & & \\
\hline Bank Muamalat Indonesia & 2.41 & 0.96 & 1.56 \\
Bank Syariah Mandiri & 1.88 & 1.44 & 1.62 \\
Bank Mega Syariah & 2.99 & 1.99 & 2.36 \\
\hline Mean & $\mathbf{2 . 4 3}$ & $\mathbf{1 . 4 6}$ & $\mathbf{1 . 8 5}$ \\
\hline
\end{tabular}

Individually, Bank Rakyat Indonesia recorded the highest financial performance for all study periods, while Bank Syariah Mandiri recorded the lowest financial performance in the pre-2008 GFC period and Bank Muamalat Indonesia both in the post-2008 and entire period. As for conventional banks, the financial performance of Bank Mandiri was in the second place after Bank Rakyat Indonesia, but it higher than the performance of Bank Negara Indonesia over all periods of study.

Interestingly, the financial performance level of Islamic banks varied across the study periods. Over all periods of the study, Bank Mega Syariah recorded the highest financial performance. In the pre-2008 GFC, Bank Muamalat Indonesia recorded the second highest performance, while in the post-2008 GFC and entire periods; the bank recorded the lowest performance. On the other hand, Bank Syariah Mandiri recorded the second highest performance in the post-2008 GFC and entire periods, but the bank has the lowest performance in the pre-2008 GFC. These findings show that the presence of 2008 GFC has adversely impacted the banking industry in Indonesia.

Furthermore, Table 3 illustrates the correlation between the performances of conventional and Islamic banks over the study period. In the pre-2008 GFC period, the financial performances of conventional and Islamic banks were strongly and positively correlated by the coefficient of 0.850 at the $10 \%$ level of significance. On the other hand, their performances' correlations become negatively significant by -0.177 at $10 \%$ level during the post-2008 GFC period. Overall, the banks' performances were weakly and positively correlated by a coefficient of 0.221 at the $1 \%$ level of significance.

Table 3. Pearson's Correlation Coefficients

\begin{tabular}{|c|c|c|c|c|c|c|}
\hline \multirow{2}{*}{$\begin{array}{c}\text { Financial } \\
\text { Performance }\end{array}$} & \multicolumn{2}{|c|}{$\begin{array}{l}\text { Sub-sample 1: } \\
\text { Pre-2008 GFC }\end{array}$} & \multicolumn{2}{|c|}{$\begin{array}{l}\text { Sub-sample 2: } \\
\text { Post-2008 GFC }\end{array}$} & \multicolumn{2}{|c|}{$\begin{array}{c}\text { Full-sample: } \\
\text { Pre-and Post -2008 GFC }\end{array}$} \\
\hline & CB & IB & CB & IB & CB & IB \\
\hline $\mathrm{CB}$ & 1.000 & $\begin{array}{l}0.850^{*} \\
(0.057)\end{array}$ & 1.000 & $\begin{array}{l}-0.177^{*} \\
(0.066)\end{array}$ & 1.000 & $\begin{array}{l}0.221^{* * *} \\
(0.003)\end{array}$ \\
\hline IB & - & 1.000 & - & 1.000 & - & 1.000 \\
\hline
\end{tabular}

Note: $\mathrm{CB}$ refers to the conventional bank, while IB refers to the Islamic bank.

"s* and indicate significance at the $1 \%$ and $10 \%$ levels, respectively. 
Our findings indicate that, in the pre-2008 GFC period, the changes in conventional banks' performances have been followed by Islamic banks' performances in the same direction. Meanwhile, in the post-2008 GFC period, the changes in performances of conventional banks have been not followed by the Islamic banks. This finding further shows that the banks have reacted to the 2008 GFC differently. The nature of Islamic banks' operation based on Islamic principles, such as riba- and gharar-free has caused the performances of Islamic banks to become less affected by the crisis. This evidence highlights the tenet of Islamic principles that the interest rate (riba) is an insignificant determinant of Islamic banking operations and performances, which is relatively higher during the crisis period (Yusof \& Majid, 2008; Majid $\&$ Yusof, 2009). Our finding provides further support that destabilizing interest rates during the crisis period would have an insignificant adverse impact on the Islamic banks (Mohd Yusof \& Majid, 2007).

\section{A Comparison between the Performances of Conventional and Islamic Banks in the Pre- and Post- 2008 GFC Periods}

Table 4 reports the findings of comparative performances between conventional and Islamic banks over the pre-2008 GFC, post-2008 GFC, and full-sample periods using the independent sample t-test.

Table 4. Comparison between Performances of Conventional and Islamic Banks in the Pre- and Post-2008 GCF Periods

\begin{tabular}{|c|c|c|c|c|c|c|c|c|c|}
\hline $\begin{array}{l}\text { Bank's Financial } \\
\text { Performance }\end{array}$ & $\mathbf{n}$ & Mean & Levene's Test & $\mathbf{F}$ & Sig. & $\mathbf{t}$ & df & $\begin{array}{c}\text { Sig. } \\
\text { (2-tailed) }\end{array}$ & $\begin{array}{c}\text { Mean } \\
\text { Differences }\end{array}$ \\
\hline \multicolumn{10}{|c|}{ Sub-sample 1: Pre- 2008 GFC } \\
\hline $\begin{array}{l}\text { Conventional Bank } \\
\text { Islamic Bank }\end{array}$ & 60 & $\begin{array}{l}5.72 \\
2.43 \\
\end{array}$ & $\begin{array}{l}\text { Equal variances } \\
\text { Unequal variances }\end{array}$ & $36.54^{* * *}$ & ${ }^{*} 0.000$ & $\begin{array}{l}8.248 \\
8.248 \\
\end{array}$ & $\begin{array}{c}118 \\
83.39 \\
\end{array}$ & $\begin{array}{l}0.000 \\
0.000 \\
\end{array}$ & $3.28^{* * *}$ \\
\hline \multicolumn{10}{|c|}{ Sub sample 2: Post 2008 GFC } \\
\hline $\begin{array}{l}\text { Conventional Bank } \\
\text { Islamic Bank }\end{array}$ & 108 & $\begin{array}{l}3.35 \\
1.46\end{array}$ & $\begin{array}{l}\text { Equal variances } \\
\text { Unequal variances }\end{array}$ & $5.85^{* *}$ & 0.017 & $\begin{array}{l}14.07 \\
14.07\end{array}$ & $\begin{array}{c}214 \\
203.96 \\
\end{array}$ & $\begin{array}{l}0.000 \\
0.000\end{array}$ & $1.89^{* * *}$ \\
\hline \multicolumn{10}{|c|}{ Full-sample: Pre-and Post- 2008 GFC } \\
\hline $\begin{array}{l}\text { Conventional Bank } \\
\text { Islamic Bank }\end{array}$ & 180 & $\begin{array}{l}4.27 \\
1.85\end{array}$ & $\begin{array}{l}\text { Equal variances } \\
\text { Unequal variances }\end{array}$ & $26.56^{*}$ & ${ }^{*} 0.000$ & $\begin{array}{l}12.93 \\
12.93\end{array}$ & $\begin{array}{c}348 \\
283.92\end{array}$ & $\begin{array}{l}0.000 \\
0.000\end{array}$ & $2.42^{* * *}$ \\
\hline
\end{tabular}

Note: $n$ shows the number of observations. ${ }^{* * *}$ and ${ }^{* *}$ indicate significance at the $1 \%$ level.

As shown in Table 4, the performances of conventional banks were higher than those of Islamic banks over the study periods, both before and after the GFC, and the findings were similar to Tables 1 and 2. This finding also confirms the discovery of the previous study by Ardiyana (2011), who documented a higher profitability ration of conventional banks as compared to their Islamic banks' counterparts. 
Table 4 also shows that there were significant differences in financial performances between conventional and Islamic banks in the periods of pre- and post-2008 GFC as well as a full-sample period at the $1 \%$ level of significance, as shown by the $\mathrm{t}$-tests for equality means and the Leven's tests for equality of variances. These findings are not surprising as the conventional banks have been long-existed compared to the newly established Islamic banks in Indonesia. A smaller market share of the Islamic banks, which was only 8.69\% in December 2019 (Otoritas Jasa Keuangan, 2020), might partially cause the difficulty for the Islamic banks to compete with the long-existing conventional banks that captured $91.31 \%$ market share in the national banking industry.

The results of our study are in harmony with the finding by Nugraha (2014), which recorded significant differences in the financial performances between Islamic and conventional banks. Betharino et al (2015) also documented the considerable differences in the performances between traditional and Islamic banks during the period 2010-2014.

Table 4 also shows the changes in the banking performances from the pre- to the post2008 GFC periods. On average, the changes in Islamic banks' performances were less deteriorated by the presence of 2008 GFC, justifying higher stability and resilience of the Islamic during the crisis period. This is evidenced by the decline in the average financial performance of Islamic banks by only 0.40 points $(16.5 \%)$ as compared to a sharply dropped in the performance of conventional by the average of 2.27 points (39.9\%) during the 5-year post-GFC period (i.e., 20092013). If a more extended period is taken, namely for nine-years post-2008 GFC period (i.e., 2009-2017), the decline in the average financial performance of Islamic banks by only 0.97 points (39.9\%) was far smaller as compared to the decrease in the average financial performance of conventional banks by 2.37 points $(41.4 \%)$.

These findings show that although both banks' financial performances have declined from the pre- to the post-2008 GFC periods, the Islamic banks had experienced a smaller decline in their performances compared to the conventional banks. In other words, the presence of 2008 GFC has hit the banking industry adversely in Indonesia, but the conventional banks have been hit hardest by the GFC than Islamic banks. In comparison, the conventional banks appeared to be more receptive to the $2008 \mathrm{GFC}$ than Islamic banks counterparts amidst the crisis period. These empirical findings highlighted the nuisances of the fragility of modern finance during the turbulent financial period. Conversely, the stability of Islamic banks during the economic turmoil was mainly due to their nature that is free from elements of interest (riba), gambling (maysir), and uncertainty (gharar)(Majid, 2018).

The superiority of Islamic banking performance over their conventional counterparts during the crisis period is supported by an earlier study conducted by Nugraha (2014). The Islamic 
banks were more efficient(Ahmad \& Pandey, 2010) and had better performance and have been less impacted by the crisis (Pratikto \& Sugianto, 2011). Besides, with a better asset and risk management quality, Islamic banks could easily shield themselves from the adverse effect of the crisis(Kassim \& Majid, 2010; Majid, Musnadi, \& Putra, 2014).

\section{A Comparison of Performances of Conventional and Islamic Banks between the Pre-and Post-2008 GFC Periods}

Table 5 illustrates the comparative findings of performances of the conventional and Islamic banks between the pre-and post-2008 GFC periods based on the paired sample t-test. The monthly financial performance of a similar group of the banks before the 2008 GFC period ranging from 2003 to 2007 (60 observations) was compared to a monthly financial performance after the 2008 GFC period spanning from 2009 to 2017 (108 observations).

As shown in Table 5, on average, conventional banks' financial performance was significantly higher during the pre-2008 GFC (5.72 points) than in the post-2008 GFC (3.44 points) periods at the $1 \%$ level. Similarly, on average, the Islamic banking performances also showed a significant decline from 2.43 points to 2.03 points at the $5 \%$ level. This finding is in line with the study by Kadir, Abdullah, Harun, Nordin, and Jaffar (2011) and Sabbina (2014), who found significant differences in Islamic banks' performances between the pre- and post2008 economic crisis. These findings further confirm that the presence of the 2008 GFC has impacted performances of the banking industry, both conventional and Islamic, in Indonesia, confirming the results by Winarso (2008) and the statement of Bank Indonesia (2010). However, the decline in the banking performances was severely experienced by the conventional banks by -2.28 points as compared to only -0.40 points experienced by the Islamic banks. This evidence confirms the more resilience, stability, and superiority of Islamic banks towards the economic crisis (Kassim \& Majid, 2010; Abduh et al., 2011; Majid et al., 2014).

Table 5. Comparison of Performances of Conventional and Islamic Banks between periods of the Pre-and Post-2008 GFC

\begin{tabular}{|c|c|c|c|c|c|c|c|}
\hline & \multicolumn{3}{|c|}{ Paired samples statistics } & \multicolumn{3}{|c|}{ Paired Differences } & \multirow[b]{2}{*}{ df $\begin{array}{c}\text { Sig. } \\
(2 \text {-tailed })\end{array}$} \\
\hline & $\mathbf{n}$ & Mean & $\begin{array}{c}\text { Mean } \\
\text { Differences }\end{array}$ & $\begin{array}{l}\text { Standard } \\
\text { Deviation }\end{array}$ & $\begin{array}{c}\text { Standard } \\
\text { Mean }\end{array}$ & $\mathbf{t}$ & \\
\hline \multicolumn{8}{|c|}{ Conventional Bank: } \\
\hline $\begin{array}{l}\text { Post-2008 GFC } \\
\text { Pre-2008 GFC }\end{array}$ & $\begin{array}{c}108 \\
60\end{array}$ & $\begin{array}{l}3.44 \\
5.72\end{array}$ & $-2.28^{* * *}$ & 2.27 & 0.29 & -7.77 & 0.000 \\
\hline \multicolumn{8}{|c|}{ Islamic Bank: } \\
\hline $\begin{array}{l}\text { Post-2008 GFC } \\
\text { Pre-2008 GFC }\end{array}$ & $\begin{array}{c}108 \\
60\end{array}$ & $\begin{array}{l}2.03 \\
2.43\end{array}$ & $-0.40^{* *}$ & 1.34 & 0.17 & -2.34 & 0.023 \\
\hline
\end{tabular}

Note: $n$ shows the number of observations. ${ }^{* * *}$ and ${ }^{* *}$ indicates significance at the $1 \%$ and $5 \%$ levels, respectively. 
Overall, our study shows that although the Islamic banks have recorded significantly lower financial performance than their conventional banking counterparts, but Islamic banks had experienced a much slower decline in their performances from the pre- to the post-2008 GFC. These findings show more superiority, stability, and resilience of Islamic banks in facing a financial crisis. Thus, to create more stability for the national economy, it is essential to promote the Islamic banking industry by enhancing its performance. All Muslim businessmen, investors, government employees, entrepreneurs, and other Muslim professions should make Islamic bank as the only choice for them to transact.

Finally, the government should provide a conducive banking environment and more capital for the Islamic bank to expand further. The government should enhance the stimulus package for Islamic banking by relaxing the rules to curtail the adverse impact of economic turbulence on the Islamic banking progress. The government should also assist the Islamic banks to accelerate the adoption of digital finance in offering their services by strengthening the existing fintech-related regulation (Nastiti \& Kasri, 2019). Having these government supports, it is believed that the Islamic banking performance can be promoted nationwide.

\section{CONCLUSION}

This study empirically compared differences in performances between conventional and Islamic banks in the pre- and post-2008 GFC periods. It also empirically compared the differences in the banking performances between the pre- and post-2008 GFC periods. Based on the independent sample t-test, the study found a significant difference between the Islamic and conventional banking performances during the pre- and post- 2008 GFC periods. The conventional banks recorded higher performances compared to their Islamic banking counterparts over all periods of the study. The longer establishment, larger size, and more significant market share of the conventional banks were among the critical factors contributing to their higher performances.

Furthermore, the study found a decline in the performances of both conventional and Islamic banks from the pre- to the post-GFC periods. However, based on the paired t-test, the reduction in Islamic banking performance from the pre- 2008 GFC to the post-2008 GFC was significantly smaller than their conventional banking counterparts. These findings show the stability and resilience of the Islamic banks over their conventional banking counterparts in facing the 2008 GFC due to their fair and just practices based on the Islamic tenets. This empirical evidence demonstrated that Islamic finance, particularly Islamic banking institution, could offer a solution to the existing financial turmoil and be a viable alternative to the episodes of turbulent economic system worldwide. Thus, to create a more stable banking system in the 
country, Islamic banks should be further strengthened and promoted. This could be done, inter alia, by providing supportive financial regulations for the Islamic banks to grow faster in the future. The government is also advised to further support Islamic banks' progress by placing more funds into Islamic banks.

Future studies might use different measures of banking performances to provide more robust and comprehensive findings on this topic, such as their contribution to poverty eradication, income inequality, and unemployment reductions. Besides, to present more reliable findings on the changes in conventional and Islamic banking performances across the financial crises, future studies could compare them across different episodes of economic crises, such as the 1997 East Asian crisis, the 2010 European debt crisis, etc. Finally, the comparative study of Islamic and conventional banking performances could also be extended by including more Islamic banks from various countries.

\section{BIBLIOGRAPHY}

Abduh, M., Omar, M. A., \& Duasa, J. (2011). The Impact of Crisis and Macroeconomic towards Islamic Banking Deposits. American Journal of Applied Sciences, 8(12), 1418.

Ahmad, M. M., \& Pandey, D. (2010). Are Islamic banks better immunized than conventional banks in the current economic crisis? 10th Global Conference on Business \& Rome, Italy.

Aliabadi, S., Dorestani,A., \& Balsara, N.(2013). The MostValue Relevant Accounting Performance Measure by Industry. Journal of Accounting and Finance, 13(1), 22-34.

Ardiyana, M. (2011). Analisis Perbandingan Kinerja Keuangan Bank Syari'ah dan Bank Konvensional Sebelum, Selama, dan Sesudah Krisis Global Tahun 2008 dengan Menggunakan Metode CAMEL (Studi Kasus pada PT Bank Syari'ah Mandiri dan PT Bank Mandiri Tbk). Undergraduate Thesis. Diponegoro University.

Bank Indonesia. (2009). Outlook Ekonomi Indonesia 2009 - 2014, Edisi Januari 2009. Jakarta: BI.

Bank Indonesia. (2010). Krisis Global dan Penyelamatan atas Sistem Perbankan Indonesia. Jakarta: BI.

Betharino, L., Susanti., \& Joko, A. (2015). Analisis Perbandingan Kinerja Keuangan Bank Konvensional dan Bank Syariah pada PT. Bank Negara Indonesia Tbk. Artikel Ilmiah

Mahasiswa. Universitas Jember.

Davies, G. (2002). A History of Money: From Ancient Times to the Present Day. The UK: University of Wales Press. 
Erol, C. F., Baklaci, H., Aydoğan, B., \& Tunç, G. (2014). Performance Comparison of Islamic (Participation) Banks and Commercial Banks in Turkish Banking Sector. EuroMed Journal of Business, 9(2), 114-128. DOI: 10.1108/EMJB-05-2013-0024.

Hazzi, O.A., \& Kilani, M.I.A.(2013). The Financial Performance Analysis of Islamic and Traditional Banks: Evidence from Malaysia. European Journal of Economics, Finance and Administrative Sciences, 57, 133-144.

Jaffar, M., \& Manarvi, I. (2011). Performance Comparison of Islamic and Conventional Banks in Pakistan. Global Journal of Management and Business Research, 11(1), 60-66.

Kadir, N. A., Abdullah, N. L., Harun, N., Nordin, N.A., \& Jaffar, A. (2011). Financial Performance of Islamic Bank in Malaysiaduring and after Economic Crisis. The 2011 IEEE Colloquium on Humanities, Science and Engineering, 839-844.

Kassim, S., \& Majid, M. S. A. (2010). Impact of Financial Shocks on Islamic Banks: Malaysian Evidence during 1997 and 2007 Financial Crises. International Journal of Islamic and Middle Eastern Finance and Management,3(4),291-305.DOI:10.1108/ 17538391011093243.

Kassim, S. H., Majid, M. S. A., \& Hamid,Z. (2011). The 2007 Global Financial Crisis and the Malaysian Stock Market:A Sectoral Analysis.Afro-Asian JournalofFinance and Accounting, 2(3), 185-209.

Kassim, S. H., Majid, M. S. A., \& Yusof, R. M. (2009). Impact of Monetary Policy Shocks on the Conventional and Islamic Banks in a Dual Banking System: Evidence from Malaysia. Journal of Economic Cooperation and Development, 30(1), 41-58.

Khan, I., Khan, M., \& Tahir, M. (2017). Performance Comparison of Islamic and Conventional Banks: Empirical Evidence from Pakistan. International Journal of Islamic and Middle EasternFinance and Management, 10(3),419-433.DOI:10.1108/IMEFM0520160077.

Kopecká, N. (2018). Aliterature Review of Financial Performance Measures and Value Relevance. In the Impact of Globalization on International Finance and Accounting, 385 393. Springer International Publishing. https://doi.org/10.1007/978-3-319-68762-9_42.

Majid, M.S.A.(2018). Stability and Resilience of Equity Markets amidst the 2008 Global Financial Crisis: Islamic versus Conventional Markets. DLSU Business \& Economics Review, 28(1), 34-48.

Majid, M. S.A., \& Kassim, S. H. (2009). Impact of the 2007 US Financial Crisis on the Emerging Equity Markets. International Journal of Emerging Markets, 4(4), 341-357.

Majid, M. S.A., Musnadi, S., \& Putra, I. Y. (2014). A Comparative Analysis of the Quality of Islamic and Conventional Banks' Asset Management in Indonesia. Gadjah Mada International Journal of Business, 6(2), 185-200. DOI: 10.22146/gamaijb.5463. 
Majid, M. S. A., \& Yusof, R. M. (2009). Long-run Relationship between Islamic Stock Returns and Macroeconomic Variables: An Application of the Autoregressive Distributed Lag Model. Humanomics: The International Journal of Systems and Ethics, 25(2), 127-141.

Mohd Yusof, R., \& Majid, M. S. A. (2007). Stock Market Volatility Transmission in Malaysia: Islamic versus Conventional Stock Market. Journal of King Abdulaziz University: Islamic Economics, 20(2), 17-35.

Nastiti, N. D., \& Kasri, R.A. (2019). The Role ofBanking Regulation in the Development of Islamic Banking Financing in Indonesia. International Journal of Islamic and Middle Eastern Finance and Management, 12(5), 643-662. DOI 10.1108/IMEFM-10-20180365. Nugraha, D.A. (2014). Analisis Perbandingan Kinerja Keuangan Bank Syariah dengan Bank Konvensional (Studi Kasus pada PT. Bank Syariah Mandiri dan PT. Bank Central Asia). Skripsi. Universitas Muhammadiyah Surakarta.

Otoritas Jasa Keuangan. (2018). Sharia Banking Statistics. Jakarta: OJK.

Otoritas Jasa Keuangan. (2020). Statistik Perbankan Syariah. Jakarta: OJK.

Pratikto, H., \& Sugianto, I. (2011). Kinerja Efisiensi Bank Syariah Sebelum dan Sesudah Krisis Global Berdasarkan Data Envelopment Analysis. Jurnal Ekonomi Bisnis, 16(2), 108-117. Rose, P. S., \& Hudgins, S. C. (2005). Bank Management and Financial Services. The UK: McGraw-Hill. Rosly, S. A., \& Bakar, M. A. A. (2003). Performance of Islamic and Mainstream Banks in Malaysia. International Journal of Social Economics, 30(12), 1249-1265.

Sabbina, A. (2014). Analisis Perbandingan Kinerja Keuangan Bank Syariah Selama dan Setelah Krisis Ekonomi Global 2008 (Studi Pada Bank Muamalat Indonesia dan Bank Syariah Mandiri Tbk). Skripsi. UIN Syarif Hidayatullah.

Setyaningsih, A., \& Utami, S. S. (2013). Analisis Perbandingan Kinerja Keuangan Perbankan Syariah dengan Perbankan Konvensional. Jurnal Ekonomi dan Kewirausahaan, 3(1), $100-115$.

Subaweh, I. (2008). Analisis Perbandingan Kinerja Keuangan Bank Syariah dan Bank Konvensional Periode 2003-2007. Jurnal Ilmiah Ekonomi Bisnis, 13(2), 112-125.

Sudarsono, H. (2009). Dampak Krisis Keuangan Global terhadap Perbankan di Indonesia: Perbandingan antara Bank Konvensional dan Bank Syariah. La Riba Jurnal Ekonomi Islam, 3(1), 12-23.

Sugema, I. (2012). Krisis Keuangan Global 2008-2009 dan Implikasinya pada Perekonomian Indonesia. Jurnal Ilmu Pertanian Indonesia, 17(3), 145-152.

Tong, H., \& Wei, S. J. (2008). Real Effects of the Subprime Mortgage Crisis: Is it a Demand of Finance Shock? NBER Working Paper No. 14205. 
Wasiuzzaman, S., \& Gunasegavan, U. N. (2013). Comparative Study of the Performance of Islamic and Conventional Banks: The Case of Malaysia. Humanomics, 29(1), 43-60. DOI: $10.1108 / 08288661311299312$.

Winarso, B. S. (2008). Perbandingan Kinerja Keuangan Bank Syariah Sebelum dan pada Masa Krisis Ekonomi: Pendekatan Model CAMEL. Logos, 6(1), 20-36.

Yusof, R. M., \& Majid, M. S. A. (2008). Towards an Islamic International Financial Hub: the Role of Islamic Capital Market in Malaysia. International Journal of Islamic and Middle Eastern Finance and Management, 1(4),313-329.https://doi.org/10.1108/ 17538390810919628. 